\title{
COVID-19 and the Workplace: Implications, Issues, and Insights for Future Research and Action
}

Kevin M. Kniffin Jayanth Narayanan Frederik Anseel John Antonakis Susan P. Ashford Arnold B. Bakker Peter Bamberger Hari Bapuji Devasheesh P. Bhave Virginia K. Choi

Stephanie J. Creary
Evangelia Demerouti
Francis J. Flynn
Michele J. Gelfand
Lindred Greer
Gary Johns
Selin Kesebir
Peter G. Klein
Sun Young Lee
Hakan Ozcelik

Jennifer Louise Petriglieri Nancy P. Rothbard Cort W. Rudolph Jason D. Shaw Nina Sirola Connie R. Wanberg Ashley Whillans Michael P. Wilmot Mark van Vugt 


\section{COVID-19 and the Workplace:}

\section{Implications, Issues, and Insights for Future Research and Action}

Kevin M. Kniffin,

Cornell University

Jayanth Narayanan

National University of Singapore

Frederik Anseel

University of New South Wales

John Antonakis

University of Lausanne

Susan P. Ashford

University of Michigan

Arnold B. Bakker

Erasmus University Rotterdam

Peter Bamberger

Tel Aviv University

Hari Bapuji

University of Melbourne

Devasheesh P. Bhave

Singapore Management University

Virginia K. Choi

University of Maryland, College Park
Stephanie J. Creary

University of Pennsylvania

Evangelia Demerouti

Eindhoven University of Technology

Francis J. Flynn

Stanford University

Michele J. Gelfand

University of Maryland, College Park

Lindred Greer

University of Michigan

Gary Johns

Concordia University

Selin Kesebir

London Business School

Peter G. Klein

Baylor University

Sun Young Lee

University College London

Hakan Ozcelik

California State University, Sacramento
Jennifer Louise Petriglieri

INSEAD

Nancy P. Rothbard

University of Pennsylvania

Cort W. Rudolph

Saint Louis University

Jason D. Shaw

Nanyang Technological University, Singapore

Nina Sirola

Singapore Management University

Connie R. Wanberg

University of Minnesota School

Ashley Whillans

Harvard Business School

Michael P. Wilmot

University of Arkansas

Mark van Vugt

Vrije Universiteit Amsterdam

\section{Working Paper 20-127}

Copyright (c 2020 by Kevin M. Kniffin, Jayanth Narayanan, Frederik Anseel, John Antonakis, Susan P. Ashford, Arnold B. Bakker, Peter Bamberger, Hari Bapuji, Devasheesh P. Bhave, Virginia K. Choi, Stephanie J. Creary, Evangelia Demerouti, Francis J. Flynn, Michele J. Gelfand, Lindred Greer, Gary Johns, Selin Kesebir, Peter G. Klein, Sun Young Lee, Hakan Ozcelik, Jennifer Louise Petriglieri, Nancy P. Rothbard, Cort W. Rudolph, Jason D. Shaw, Nina Sirola, Connie R. Wanberg, Ashley Whillans, Michael P. Wilmot, and Mark van Vugt.

Working papers are in draft form. This working paper is distributed for purposes of comment and discussion only. It may not be reproduced without permission of the copyright holder. Copies of working papers are available from the author.

Funding for this research was provided in part by Harvard Business School. 


\begin{tabular}{|c|}
\hline June 5, 2020 Draft \\
Not Yet Peer-Reviewed \\
Please do not copy or cite without the authors' permission \\
\hline
\end{tabular}

\section{COVID-19 and the Workplace:}

\section{Implications, Issues, and Insights for Future Research and Action}

Kevin M. Kniffin ${ }^{1}$, Jayanth Narayanan ${ }^{2}$, Frederik Anseel ${ }^{3}$, John Antonakis ${ }^{4}$, Susan P. Ashford ${ }^{5}$, Arnold B. Bakker ${ }^{6}$, Peter Bamberger ${ }^{7,8}$, Hari Bapuji ${ }^{9}$, Devasheesh P. Bhave ${ }^{10}$, Virginia K. Choi $^{11}$, Stephanie J. Creary ${ }^{12}$, Evangelia Demerouti ${ }^{13}$, Francis J. Flynn ${ }^{14}$, Michele J. Gelfand ${ }^{11}$, Lindred Greer $^{5}$, Gary Johns ${ }^{15,16}$, Selin Kesebir ${ }^{17}$, Peter G. Klein ${ }^{18}$, Sun Young Lee ${ }^{19}$, Hakan Ozcelik $^{20}$, Jennifer Louise Petriglieri ${ }^{21}$, Nancy P. Rothbard ${ }^{12}$, Cort W. Rudolph ${ }^{22}$, Jason D. Shaw $^{23}$, Nina Sirola ${ }^{10}$, Connie R. Wanberg ${ }^{24}$, Ashley Whillans ${ }^{25}$, Michael P. Wilmot ${ }^{26}$, and Mark van $\operatorname{Vugt}^{27}$

\section{Author Note}

Kevin M. Kniffin, Jayanth Narayanan, and Mark van Vugt conceptualized the article and wrote the original and revised versions with multiple rounds of input, editing, and review by each additional co-author (listed alphabetically by last name) Frederik Anseel, John Antonakis, Susan P. Ashford, Arnold B. Bakker, Peter Bamberger, Hari Bapuji, Devasheesh P. Bhave, Virginia K. Choi, Stephanie J. Creary, Evangelia Demerouti, Francis J. Flynn, Michele J. Gelfand, Lindred Greer, Gary Johns, Selin Kesebir, Peter G. Klein, Sun Young Lee, Hakan Ozcelik, Jennifer Louise Petriglieri, Nancy P. Rothbard, Cort W. Rudolph, Jason D. Shaw, Nina Sirola, Connie R. Wanberg, Ashley Whillans, and Michael P. Wilmot.

\section{Corresponding Author:}

Kevin M. Kniffin

Dyson School of Applied Economics and Management

SC Johnson College of Business

Cornell University

email: kmk276@cornell.edu 
${ }^{1}$ Dyson School of Applied Economics and Management, SC Johnson College of Business, Cornell University

${ }^{2}$ National University of Singapore

${ }^{3}$ UNSW Business School, UNSW Sydney

${ }^{4}$ University of Lausanne

${ }^{5}$ Stephen M. Ross School of Business, University of Michigan

${ }^{6}$ Center of Excellence for Positive Organizational Psychology, Erasmus University Rotterdam

${ }^{7}$ Coller School of Management, Tel Aviv University

${ }^{8}$ Smithers Institute, Cornell University

${ }^{9}$ University of Melbourne

${ }^{10}$ Singapore Management University

${ }^{11}$ University of Maryland, College Park

12 The Wharton School, University of Pennsylvania

${ }^{13}$ Eindhoven University of Technology

${ }^{14}$ Graduate School of Business, Stanford University

${ }^{15}$ John Molson School of Business, Concordia University

${ }^{16}$ Sauder School of Business, University of British Columbia

${ }^{17}$ London Business School

${ }^{18}$ Hankamer School of Business, Baylor University

${ }^{19}$ UCL School of Management

${ }^{20}$ California State University, Sacramento

${ }^{21}$ INSEAD

${ }^{22}$ Saint Louis University

${ }^{23}$ Nanyang Technology University, Singapore

${ }^{24}$ University of Minnesota

${ }^{25}$ Harvard Business School

${ }^{26}$ Sam M. Walton College of Business, University of Arkansas

${ }^{27}$ Vrije Universiteit Amsterdam 


\title{
COVID-19 and the Workplace:
}

\section{Implications, Issues, and Insights for Future Research and Action}

\begin{abstract}
COVID-19's impacts on workers and workplaces across the globe have been dramatic. We present a broad review of prior research rooted in work and organizational psychology, and related fields, for making sense of the implications for employees, teams, and work organizations. Our review and preview of relevant literatures focuses on: (i) emerging changes in work practices (e.g., working from home, virtual teams) and (ii) economic and socialpsychological impacts (e.g, unemployment, mental well-being). In addition, we examine the potential moderating factors of age, race and ethnicity, gender, family status, personality, and cultural differences to generate disparate effects. Illustrating the benefits of team science, our broad-scope overview provides an integrative approach for considering the implications of COVID-19 for work and organizations while also identifying issues for future research and insights to inform solutions.
\end{abstract}

Keywords: COVID-19; Employees; Work; Work From Home (WFH); Pandemics 
COVID-19 is both a global health crisis and an international economic threat. The worldwide lockdown of businesses and industries that were implemented and mandated to curb the spread of the virus generated a wide array of unique and fundamental challenges for both employees and employers across the globe. At the individual level, populations of shutdownaffected employees were turned overnight into (a) "work from home” employees, (b) “essential” or "life-sustaining" workers (e.g., emergency room medical personnel and supermarket staff), or (c) furloughed or laid-off employees seeking the nation-specific equivalent of unemployment benefits. Organizationally, the economic shutdowns and related governmental activities appear likely to (i) change some industries fundamentally, (ii) accelerate trends that were already underway in others, and (iii) open opportunities for novel industries to emerge, as typically happens in times of wars and natural disasters (e.g., Sine \& David, 2003). Given the uncertainty and breadth of the COVID-19 shock, work and organizational psychologists urgently need to apply the field's current knowledge for the purpose of sensemaking to help individuals and organizations manage risks while developing and applying solutions.

Among the present unknowns, it is possible that an effective vaccine or therapeutic treatment becomes available quickly enough to limit the direct impacts of COVID-19 to less than a year. Among relevant knowns, though, a look at human history and prehistory is filled with cases where pathogenic microbes (including viruses and bacteria) have wreaked havoc on societies and workplaces (Diamond, 1998). As an example, between 1918-1920, the Spanish flu killed an estimated 50 million people worldwide, many of them adults between the ages of 20 and 50 years. In response, many countries adopted policies to improve health and working conditions by providing either universal health care (Europe) or employer-based insurance schemes (US). More generally, the financial and health impacts of infectious disease have been 
linked to tighter cultural norms and practices (Gelfand, 2019), political conservatism and xenophobia (Ji, Tybur \& Van Vugt, 2019), and more directive workplace leadership (Van Vugt, Hogan, \& Kaiser, 2008). We also know, when considering other recent systemic shocks such as the 9/11/2001 attacks in the United States, that such shocks can produce long-lasting global changes in practices and attitudes towards surveillance, security, and privacy.

In the analysis we present here, we focus on the relevance of COVID-19-related risks and changes for workers, workplaces, and work practices - and do not differentiate between the direct health risks associated with COVID-19 and the economic fallout. Our broad survey of topics allows us to identify a variety of economic, social, and psychological risks that workers appear likely to face as a result of COVID-19; and, notably, some of these risks are those that research on prior economic contractions suggests may have adverse - and lethal - health effects (e.g., Popovici \& French, 2013). By organizing our experiences as researchers in a wide array of topical areas, we present a review of relevant literatures along with an evidence-based preview of changes that we expect in the wake of COVID-19 for both research and practice. To organize our consideraton of the multiple ways in which the current pandemic is impacting the workplace, this review consists of three main sections: (1) emergent changes in work practices that have been necessary in response to the pandemic, including mandatory working from home, often in virtual settings, on unprecedented scales; (2) economic and social-psychological impacts that are visible in the wake of COVID-19, including unemployment, mental illness, and addiction; and, (3) the importance of moderating factors (e.g., age, race and ethnicity, gender, personality, family status, and culture) for which there are likely to be disparate COVID-19 impacts.

Beyond reviewing and applying prior research to help make sense of the crisis, we aim to provide a generative overview to help situate and guide future research and theorizing on the 
impacts associated with COVID-19. In addition, we hope that our effort will help researchers and practitioners take steps to manage and mitigate the negative effects of COVID-19 and start designing evidence-based roadmaps for moving forward. Our effort is partly modeled on Van Bavel and colleagues' (2020) engagement of COVID-19 in relation to topics such as how people tend to respond emotionally and interpersonally in situations of uncertainty and fear. Regarding the application of provisional-by-nature knowledge from the social and behavioral sciences to understanding and responding to COVID-19, we agree with the cautions recommended by IJzerman et al. (2020). In this team-produced review and preview of literatures relevant to work and organizational psychology that leverages the benefits that can be gained through cooperation among researchers with differential expertise (Kniffin \& Hanks, 2018), we embrace and apply the case study approach that is common across the classrooms of professional schools - to work with the knowledge and information that is available - while providing a holistic narrative review (Baumeister \& Leary, 1997). Given the wide-ranging impacts of COVID-19, our focus on work and organizational psychology is intended to be aptly broad and inclusive but there are inevitably additional “workplace” topics outside of our scope (e.g., handwashing and hygiene).

\section{Emergent Changes in Work Practices}

While COVID-19 abruptly upended normal work routines, it also caused an acceleration of trends that were already underway involving the migration of work to online or virtual environments. A key difference when considering research on practices such as Work From Home (WFH) prior to the pandemic, though, is that WFH was previously often responsive to employee preferences but COVID-19 forced many into Mandatory Work From Home (MWFH). Work from Home (WFH). A Gartner (2020) survey of 229 Human Resources (HR) departments showed that approximately one-half of the companies had more than $80 \%$ of their 
employees working from home during early stages of the COVID-19 pandemic - and estimated substantial long-term increases for remote work after the pandemic. The need for millions of workers to WFH in response to COVID-19 has accelerated recent remote work trends facilitated by the rise of connectivity and communication technologies. While "remote work" is a broader category since it can include Work From Anywhere (i.e., not necessarily home), we do know that some - such as professionals who need to perform complex tasks that require little interaction with peers - actually prefer and are more productive if they WFH (Allen, Cho, \& Meier, 2014). Yet as large numbers of workers are forced to work from home, many face challenges due to such fundamental issues as not having space in one's home to attend to work. Employees who live with others also face a larger set of challenges than those who live alone since they need to navigate others' space as well (see later section on Family Status).

Employees often find it challenging to maintain boundaries between work and non-work (Ramarajan \& Reid, 2013). The forced confinement of workers during the COVID 19-pandemic has further complicated this issue. While WFH might sound appealing if it offers a safe harbor, the absence of separation between one's work and home - and the lack of commutes to provide a transition between the two domains - can become a burden too. Questions that would benefit from closer study include: how do our experiences in the work and non-work domains influence each other, and how do our work and non-work identities interact, when they unfold at home?

One domain that might offer lessons - in addition to being increasingly important independently - is the experience of gig workers (i.e., people taking on very-short-term jobs [Ashford, Caza \& Reid, 2018]) since they often Work From Anyhwere (e.g., as drivers, shoppers, and delivery people). Reflective of the gig economy's expansion prior to COVID-19: in the US, at least, 20\% of the current workforce are freelance workers (McKinsey \& Co, 2016), 
and that number has been predicted to grow to $40 \%$ by the mid-2020s (Gillespie, 2017).

Remarkably, labor economists estimate that all of the net job growth between 2005 and 2015 was in this sector (Katz \& Kruger, 2016). While so-called rideshare companies were shut down as part of the first wave of reactions to the COVID-19 outbreak, a corresponding boom in various delivery services staffed by gig workers shows the growth potential of such jobs.

The challenges that gig workers are known to face will sound familiar to those required to WFH since they include getting and staying organized; managing the heightened emotions associated with such work; figuring out and maintaining an identity so that those emotions do not disrupt the productivity upon which their survival depends; coping with loneliness while also seeking out and maintaining functional relationships that support the work; and, establishing some semblance of a longer-term career (Ashford et al., 2018). While it would not have been anticipated prior to the pandemic, future research into understanding participation and participants in the gig economy - starting with the assumption of economic precarity as a fact of life (Petriglieri, Ashford, \& Wrzesniewski, 2019) - now appears likely to offer relevance for understanding (mandatory) WFH.

As with challenges, "best practices” for WFH can also benefit from what we know has been helpful for gig workers (since they also typically do not work in traditional office settings). Such practices include actions to generate and maintain connections; actions to focus and inspire their work; explicit routines that enable the work and provide boundaries between work and home; and, both a place where the work is performed as well as an underlying purpose for the work that enables and inspires productivity as circumstances become challenging (Petriglieri et al., 2019). Future research is also needed that examines patterns in individual cognition cognitive and learning agility, general proactivity, emotional resilience, and relational skill to 
better understand and enable individuals to not only survive in this new world of work, but also to thrive (Ashford et al., 2018).

Given the likelihood that COVID-19 will accelerate trends towards WFH past the immediate impacts of the pandemic (Gartner, 2020), it is clear that the variable ways in which people work outside of traditional workplace settings will warrant growing amounts of attention for both research and practice. Future research should examine whether and how the COVID-19 quarantines that required millions to work from home affected work productivity, creativity, and innovation. Given that the quarantine period entailed a literal window into the homes of coworkers as well as subordinates and superiors, research is also needed to examine the implications of WFH for topics such as motivation and authenticity at work, particularly when it becomes normal again to work in co-located workplace settings.

Independent from challenges that individuals can face when WFH, it is also notable that (a) the reluctance of many employers to adopt WFH before COVID-19 stemmed from a perceived lack of control that employers would have over employees who were out-of-sight and -reach and (b) there is ample reason to expect that new modes of surveillance will accompany various WFH arrangements. Indeed, even before COVID-19, employers were adopting and developing technologies to monitor employees’ whereabouts (e.g., with sociometric sensors) (Bhave, Teo \& Dalal, 2020). Although managing-by-walking-around is not feasible when people are working remotely, the rapidly expanded usage of videoconferencing has allowed for virtual sight-lines. Yet these virtual sight-lines are fraught with a risk: they can increase perceived stress through continuous monitoring and feelings of privacy invasion. There is also evidence that such remote and automated monitoring can increase the centralization of management and (in the 
absence of countervailing action) likely contribute to an adverse dampening of creativity among employees working in lower organizational levels (Nell et al., 2020).

Virtual Teams. As Mak and Kozlowski (2019) observed before the pandemic, "Virtual teams ... are growing in number and importance.” Rather than assume uniformity in virtual team characteristics, though, it is valuable to recognize that "team virtuality" is a multi-facted concept and encompasses multiple dimensions including the geographical distribution of team members and the relative amounts of (a)synchronous e-communication (Hoch \& Kozlowski, 2014). Indeed, a nuanced conceptualizing of virtuality - as a continuous variable, given that teams are not simply either face-to-face or virtual - has already been developed (Mak \& Kozlowski, 2019) and should prove helpful for future researchers who work to classify the myriad forms of virtual teamwork that have been thrust on workers via COVID-19.

Prior research shows that virtual teamwork tends to lack the communication richness available to face-to-face teams (Martins, Gilson, \& Maynard, 2004) and that traditional teamwork problems such as conflict and coordination can escalate quickly in virtual teams (Mortensen \& Hinds, 2001). Building structural scaffolds to mitigate conflicts, align teams, and ensure safe and thorough information processing are key recommendations for virtual teams. For example, prior work has shown the need - especially in virtual teams - to formalize team processes, clarify team goals, and build-in structural solutions to foster psychologically safe discussions (e.g., Gibson \& Gibbs, 2006; Huang et al., 2002).

Increased team virtuality as a result of COVID-19 may also affect helping and prosocial behavior. While physical distancing among co-workers may reduce helping behaviors in the near term, we know that people should be bolder to request help from others since people do tend to be more willing to help, and give better-quality help, than we usually assume (Flynn \& Lake, 
2008; Newark, Bohns, \& Flynn, 2017), perhaps especially during crises. Normal impediments to requesting help center on the feeling that it can be uncomfortable, awkward, and embarrassing (e.g., Bohns \& Flynn, 2010), but “best practices” in helping can assist help-seekers in overcoming these psychological barriers by maintaining personal privacy (Cleavenger \& Munyon, 2017), reducing stigmatization (Ben-Porath, 2002), and instilling hope that things will get better once help is received (McDermott, et al., 2017).

As COVID-19 has accelerated the expansion of virtual teams, it will be valuable for researchers to track and study innovations that may enable such teams to function optimally. For example, the intersection of remote work with a global crisis brings up questions of how emotions, such as anxiety and stress, can best be communicated and regulated in the unique setting of virtually connected work where social and emotional cues are relatively limited (for an overview, see Lindebaum, Geddes, \& Jordan, 2018). On the other hand, there are prior studies showing that teams operating online tend to be more effective at brainstorming than face-to-face teams (e.g., DeRosa, Smith, \& Hantula, 2007) at the same time that research focusing on individual performance has shown that remotely-interacting teammates appear to miss the creative benefits that can flow from frequent face-to-face interactions (Allen, Golden, \& Shockley, 2015). The rapid growth in virtual teams offers an opportunity to examine new questions as well as develop interventions to help improve teamwork in virtual settings; and, in that pursuit, close attention needs to paid to the multidimensional ways in which virtuality varies among remote teams (Mak \& Kozlowski, 2019).

Virtual Leadership and Management. The role of leaders to determine organizational outcomes that have a broad impact on employees at all levels is especially clear in the crucible of a crisis and certainly vital in fundamental ways (Antonakis \& Day, 2017). With the COVID-19 
crisis requiring millions of employees across different hierarchical levels to work from home, it is encouraging to note that leadership can also work well from a distance (Antonakis \& Atwater, 2002). Prior research shows that successful leaders are those skilled to make the right decisions and provide reassurance through a balanced mix of optimism and realism regarding the future. In other words, effective leaders strive (in any time period) to project vision - a symbolic state of affairs with which the collective identifies (Antonakis et al., 2016). Additionally, research indicates that the absence of traditional physical cues of dominance and status in virtual settings (Antonakis \& Atwater, 2002) can foster more participatory relationships.

Research on the effectiveness of leaders during and after the COVID-19 crisis should examine an array of activities, including the degree to which remote leaders are persuasive if they (a) clearly state their values that will guide institutional actions; (b) understand and openly discuss the travails and hopes of their organizations; (c) clearly communicate an ambitious vision of the direction that the unit will head toward; and, (d) demonstrate confidence that strategic goals can be achieved. These skills are referred to as charisma (Antonakis, et al., 2016; Grabo, Spisak, \& Van Vugt, 2017) and require training and investment. Indeed, crises can bring about changes in leadership styles (Stoker, Garretsen, \& Soudis, 2019); thus, firms can expect to be better prepared by ensuring they have adequately invested in professional development. In this respect, future research should estimate if and how organizational commitments to employees’ professional development during the COVID-19 crisis pay later dividends.

Among the more specific leader-subordinate activities that will be important to consider in relation to COVID-19 is how assessment and appraisal systems will function. For example, without being able to directly monitor subordinates in the way that office settings allow, there may be a shift to results-focused assessment, which prior research shows to be generally 
effective (Pritchard et al., 2008). Over longer spans of time, though, working remotely may reduce the opportunities for subordinates to gain feedback from leaders and prior research suggests that a lack of learning opportunities is associated with lower organizational commitment and higher risk of turnover (Vandenberghe et al., 2019). In addition, future research should examine how trust can be built remotely with online interactions so that newcomers are not disadvantaged due to the lack of face-to-face interactions with their leaders (Dunbar, 2018).

\section{Economic and Social-Psychological Impacts}

In addition to the immediate impacts of COVID-19 for various workplace practices and arrangements, there is also likely to be a diverse range of social and economic costs of the pandemic for individuals, including those who lost jobs as well as those who remain employed.

Unemployment and Layoffs. As entire industries such as travel, hospitality, sports, and entertainment were shut down by COVID-19, tens of millions of people in the U.S. alone filed new unemployment claims in early 2020. In addition to losing income, we know that individuals who are unemployed may experience a range of stress-related consequences including depression, anxiety, and physical ailments (Wanberg, 2012). Jahoda's (1982) latent deprivation model helps explain the negative effects of unemployment on psychological well-being by acknowledging that employment provides both manifest (e.g., income) and latent (e.g., time structure, social contact, sharing of common goals, status, and activity) benefits. Financial deprivation can be particularly devastating, triggering a spiral of adversity that can affect the entire family (McKee-Ryan \& Maitoza, 2018).

Hopes related to COVID-19 unemployment have centered on an economic recovery unfolding fast enough that jobs lost to COVID-19 unemployment will largely be regained but that is far from certain. The broad-based closures associated with COVID-19 have further 
complicated typical advice for individuals who are unemployed to develop a regular routine of job search (Wanberg, Ali, \& Csillag, 2020). Researchers studying unique features of COVID-19 will want to compare how people cope and adapt to the shocks entailed by COVID-19 in both the near-term with respect to the employer that let them go and, in the longer term, where career adaptability (Klehe et al., 2012) - the willingness and interest to explore new options and future work scenarios - might prove to be increasingly valuable.

In addition to the consequences of unemployment for individuals, there are negative spillover effects for those who remain employed. Prior research shows that when firms reduce overall staffing levels, there tends to be correspondingly lower levels of organizational commitment, job involvement, and greater stress among survivors (Trevor \& Nyberg, 2008). Meta-analytic evidence finds that overall reduction in staffing has roughly the same adverse organizational performance as comparable voluntary turnover (e.g., Park \& Shaw, 2013). We also know from recent research that broader economic downturns tend to be associated with a shift towards more "zero-sum” mindsets with a downstream consequence that people become increasingly prone to misconstrue others as competitors even when they are not (Sirola \& Pitesa 2017). Future research that examines the mass layoffs entailed by COVID-19 should test the extent to which prior research holds up in the face of the wide, broad, and abrupt layoffs.

Presenteeism. Among those continuing to work in the wake of COVID-19, there is likely to be growth in presenteeism (i.e., people going to work when ill) (Johns, 2010). Most research on presenteeism does not distinguish between contagious and noncontagious illness; however, recent studies in Poland (Mikos et al., 2020) and Australia (Imai et al., 2020) found that approximately $20 \%$ of people diagnosed with the flu did not take sick leave. A meta-analysis of the correlates of presenteeism (Miraglia \& Johns, 2016) suggests two profiles of people who 
attend work when ill: (1) people who essentially feel forced to attend due to heavy job demands, including excessive workload, understaffing, and required overtime and (2) to a lesser extent, people who are committed to their organization and/or highly engaged in their work. Knowledge of this prior research offers helpful avenues for understanding organizational "hotspots” where COVID-19 or any other contagion might be more likely to occur (e.g., long-term care facilities).

Although comprehensive access to paid sick leave is normal in most industrialized countries, the variation across jurisdictions in the U.S. where it is not mandated warrants closer attention (e.g., Pichler \& Ziebarth, 2017). Independent of policies regarding presenteeism, Dietz, Zacher, Scheel, Otto, and Rigotti (2020) found that work team members tended to imitate the level of presenteeism exhibited by their supervisors. Compensation policies should also be reviewed in this context to help ensure that there are not incentives for co-workers to pressure each other to attend to work while sick (Kessler, 2017). Notably, for people with jobs that can be done remotely, research should examine how sickness is navigated in the post-COVID-19 workscape (e.g., to see if sick days or snow/weather days are now expected to be WFH days).

Economic Inequality. As a broader cost associated with the pandemic, many analysts expect that inequality will increase in the wake of COVID-19 just as it has in recent shocks such as the 2008 financial crisis (Wisman, 2013). Such inequalities are known from past shocks to provide differential resources and opportunities for individuals to gain employment and promotions while exacerbating inequalities in pay and benefits (Bapuji, Ertug \& Shaw, 2020).

Given prior work showing that organizational and societal inequalities feed into each other, there are grave reasons to be concerned that growth in inequality after COVID-19 will contribute to a downward spiral of negative trends in the workplace in the form of decreased work centrality, and increased burnout, absenteeism, deviant behaviors, bullying, and turnover 
(Bapuji et al., 2020). Further, it is likely that job insecurities post-COVID-19 will motivate greater risk-taking and presenteeism among low-paid workers that, in turn, may increase public health risks for further spread of the disease. Therefore, greater organizational investments to minimize inequality should dampen the negative spiraling that is otherwise likely to unfold.

Social Distancing and Loneliness. The loss of social connections - for those who were laid off and those required to WFH - is a less obvious impact of COVID-19; however, we know from research that high-quality social interactions - including informal chats among co-workers - are essential for mental and physical health (Mogilner, Whillans \& Norton, 2018). Handshakes are another social activity we know to be valuable (e.g., Schroeder et al., 2019) that can no longer be practiced. Against this backdrop, both the requirement to WFH and plans to de-densify workplaces in support of physical distancing are likely to have side effects that include at least some degree of harm to individuals' mental and physical health (Brooks et al., 2020).

More extreme than the loss of social connections, loneliness is a psychologically painful emotion that results from people's subjective feelings that their intimate and social needs are not adequately met (Cacioppo et al., 2006) and was already considered “an epidemic” (Murthy, 2017) prior to COVID-19. Workplace loneliness has been shown to have strong negative relationships to employees’ affective commitment, affiliative behaviors, and performance (Ozcelik \& Barsade, 2018). While we noted that virtual communications lack richness, a more negative risk of communications going online is that misunderstandings - in the absence of nonverbal cues - are likely to increase employees’ concerns about being interpersonally rejected, which is a major trigger for loneliness (Cacioppo et al., 2006).

As organizations develop paths forward in the wake of COVID-19, prior research recommends that workplace loneliness be acknowledged and addressed as an indicator of 
employee well-being in HR policies, programs, and practices. Close study of innovations that people started initiating within weeks of mandatory shutdowns (e.g., Virtual Happy Hours) would also be valuable for informing future practice as well as research intended to help prevent loneliness and increase resilience. Such investigations would complement recent work focused on developing resiliency through experimentally tested interventions (Williams et al., 2018).

Stress and Burnout. The ambiguity and uncertainties effected by COVID-19 have required organizations to act to protect employee health and well-being. Building upon Job Demands-Resources (JD-R) theory (Bakker \& Demerouti, 2017), we can observe that there is variation across and within industries with respect to how COVID-19 has affected both the demands and resources associated with given jobs and that there is evidence suggesting that working conditions have deteriorated for most employees, perhaps especially for frontline workers in healthcare. In light of such strains, COVID-19 has substantially contributed to greater risk of employees encountering job burnout - a chronic stress syndrome, including chronic feelings of exhaustion and a distant attitude toward work (Demerouti et al., 2010). Moreover, the continuous exposure to COVID-19 news fosters rumination - repetitively and passively focusing on symptoms of distress and on the possible causes and consequences of these symptoms (Nolen-Hoeksema et al., 2008). As suggested by studies showing that people who were exposed to Hurricane Katrina had above-baseline stress and depression symptoms a year after the event (Obradovich et al., 2018), mental health problems may remain long after a crisis.

In order to adequately deal with pandemic-specific and generically uncertain job demands, employees will need resources. To help address this, organizations may use top-down (or may facilitate bottom-up) interventions to take care of employee health and well-being with a goal to restore balance between job demands and resources. As a starting point (and part of the 
reason for our own synthesis), organizations and their leaders need to learn effective sensemaking and provide means that preserve employee well-being and performance (Combe \& Carrington, 2015) by providing (a) immediate tangible resources, such as information (e.g., about working from home, prevention of transmission), employee assistance programs (EAPs), or access to counseling, therapy, and training; and (b) psychological resources such as feedback, support, and inspiration through regular contact with their employees using video calls. Research that tracks and identifies which variants of such efforts are most effective will yield benefits beyond the systemic shocks effected by COVID-19. In addition, future research should determine whether structural efforts to optimize working conditions via job redesign and job crafting can be as effective now as compared to pre-COVID-19 (Oprea et al., 2020).

Addiction. While it is well known that traumatic events such as the 9/11/2001 attacks can precipitate societal shifts in alcohol consumption (Vlahov et al., 2002), the COVID-19 pandemic is particularly concerning since massive unemployment and mandatory WFH orders may heighten vulnerabilities and thus trigger or exacerbate alcohol use disorders (i.e., alcohol abuse or dependence), a diagnosis applicable to nearly 13\% of Americans and 20\% of Europeans (Grant et al., 2017). Prior research has shown that workforce disengagement can be associated with a decrease in alcohol misuse due to distancing from workplace-based norms to drink (Bamberger \& Bacharach, 2014). However, there is also evidence that proximity to work-based peers and supervisors (which is largely absent when employees WFH) can provide essential stress-attenuating support in times of crisis that can prevent alcohol-based coping (Bacharach, Bamberger \& Sonnenstuhl, 1996; Spicer \& Miller, 2005).

Beyond traditional EAPs, peer assistance programs including union-sponsored (e.g., AFA's member assistance program), joint labor-management-sponsored (e.g., UAW- 
Ford ESSP), and employee-initiated (e.g., Google’s Blue-Dot) programs have shown particular efficacy in times of crisis (Golan, Bacharach \& Bamberger, 2010), not only for those actively employed, but for those disengaged from work as well (Bamberger \& Bacharach, 2014). Practitioners can also consider internet-based brief interventions incorporating personalized norm-feedback (demonstrating, for example, that the individual's drinking behavior is excessive relative to his/her cohort) and/or textual or video-based insights for addressing the kinds of negative emotional states potentially driving alcohol-based self-medication since both kinds of approaches have also demonstrated efficacy (Brendryen et al., 2017). As face-to-face support becomes scarce with social distancing, such personalized and adaptive virtual technologies may well offer an important new means to assist those returning to a pandemic-adjusted workplace, working from home, or unfortunately forced to search for a new job. We anticipate that research that further examines complementary innovations might also provide more general help for researchers focused on helping employees avoid other forms of addiction as well.

\section{Moderating Factors}

Compounding changes and impacts reviewed in the previous two sections, it is also the case that there are moderating variables whereby patterns influenced by COVID-19 will disparately impact (and be impacted by) employees with certain demographic characteristics and personality traits. While we focus - in the subsections that follow - on moderators for which there exists evidence relevant to COVID-19, there are ample reasons to expect that these interact with additional factors such as a person's socio-economic or health status (i.e., chronic illnesses).

Age. Preliminary analyses of COVID-19 indicate that older people are disproportionately at-risk of dying if they are infected thereby warranting substantial attention to age. Declining birthrates and increasing life expectancy in the past century has led to an aging workforce across 
the globe (see Rudolph, Marcus, \& Zacher, 2018 for a review). COVID-19 clearly presents a number of challenges for understanding age at work, and the aging workforce. For example, ageist sentiments and narratives of intergenerational tension to explain various aspects of the pandemic in relation to work started appearing in early 2020 (Rudolph \& Zacher, 2020).

Given the health risks faced by older employees as well as early retirement incentives that we anticipate organizations dealing with budget shortfalls to offer, it is possible that the post-COVID workplace is less diverse with respect to age. On the other hand, to the degree that COVID-related losses in employees’ defined contribution retirement plans prompt older workers to delay retirement continue working, it is possible that we will see increased age diversity in the workplace resulting from this crisis (e.g., Van Solinge \& Henkens, 2014). Increased age diversity of the workforce may have several advantages for organizations, and researchers and policy makers should focus on integrating and harnessing these as opportunities. Interventions suggested by prior research include encouraging (re)recruiting retired employees as part of “return to work" schemes and developing cross-age mentoring and knowledge-sharing initiatives to "build up” human capital and strengthen internal labor markets (Brooke \& Taylor, 2005).

Race and Ethnicity. Similar to age, fatality rates for contracting COVID-19 have also varied substantially by race (e.g., within the U.S.) with speculation that the racial differences reflect underlying differences in pre-existing health conditions, lower socioeconomic status, and dense living conditions. Additionally, members of racial and ethnic minority groups are less likely to be able to work remotely and as a result face greater exposure to the virus. In the UK, healthcare professionals from Black, Asian, and Minority Ethnic (BAME) groups represent 20 percent of nurses and midwives and 44 percent of doctors and dentists (Cook, Kursumovic, \& Lennane, 2020); however, 70 percent of healthcare professionals who have died from the virus 
come from these same groups (Cookson \& Milne, 2020). In the US, Black and Hispanic/Latino people represent 13 percent and 18 percent of the population, respectively, but are dying at nearly twice the rate of Whites in New York City (New York City Department of Health and Mental Hygiene, 2020). These statistics are unsurprising given that Black and Hispanic/Latino workers represent more than 60 percent of frontline workers deemed essential in New York City during the pandemic (New York City Office of the Comptroller, 2020).

Research on diversity in the workplace is critical for understanding and mitigating the harmful effects of COVID-19. Specifically, research on bias and discrimination in organizations suggests that racial and ethnic minorities are more likely to work under harmful working conditions (Hirsh \& Kornrich, 2008) and report lower levels of supervisor support (PaustianUnderdahl et al., 2017). Although much is known about bias and discrimination in the workplace, we know less about how to mitigate them. To date, organizational scholars and psychologists have proposed individual-level coping strategies (Smith et al., 2019), interpersonal identity management strategies (Creary, Caza, \& Roberts, 2015), and organizational-level interventions such as diversity training (Nkomo \& Hoobler, 2014) that can improve racial and ethnic minorities’ experiences at work. Missing from the literature is an understanding of whether these strategies are similarly effective under conditions of economic uncertainty when racial and ethnic minorities are particularly vulnerable to layoffs (Elvira \& Zatzick, 2002). Not only should scholars who are legally able to collect racial and ethnic data continue to do so during, and beyond this pandemic, organizational and managerial interventions aimed at improving the workplace conditions and experiences of racial and ethnic minorities including their experiences of inclusion (Roberts, Mayo, \& Thomas, 2019) and belonging (Good, Rattan, \& Dweck, 2012) will be valuable. 
Gender. COVID-19 likely affects gender in a variety of ways. Higher fatality rates for men imply that male workers might need greater physical protection from the virus. Yet, there are economic and psychological reasons to suspect that women face greater occupational risks. First, women tend to work in positions that are more directly affected by COVID-19 and more easily replaceable (e.g., hospitality, cleaning, and domestic work) (Alon et al., 2020). Second, since women tend to have higher empathy (Bloise \& Johnson, 2007; Eisenberg \& Lennon, 1983), women tend to experience more distress from stressful life events, particularly the ones affecting others (Kessler \& McLeod, 1984). Given the well-established link between distress and performance (Bhagat, 1983), work disruptions may be more severe for women. Indeed, a recent survey of 996 U.K. healthcare workers found that more women are experiencing distress and job disruption amid the pandemic (IPPR, 2020).

Globally, several female leaders (e.g., Angela Merkel, Tsai Ing-wen) have tackled COVID-19 effectively. Whereas this contrasts with prior research indicating that people prefer a masculine leader in times of crisis (e.g., Van Vugt et al., 2008), a set of feminine values and traits can also be effective in crisis management, including: a communal orientation in moral decision-making (Gilligan, 1982; Tinghög et al., 2016); higher sensitivity to risk (Eckel \& Grossman, 2008), particularly about health issues (Flynn, Slovic, \& Mertz, 1994); higher conscientiousness (Schmitt, Realo, Voracek, \& Allik, 2008); and, more attentive communication styles (Campbell, 2013). Combining these insights, it is plausible that a feminine style of leadership might become recognized as optimal for dealing with crises in the future.

Family Status. Individual family status (e.g., living alone; with others; with young children) appears likely to disparately affect how COVID-19 impacts individuals’ life and work. For example, how will households with one or two working parents typically be affected by 
requirements to work from home, especially if they are responsible for one or more school-age children who they are concurrently required to homeschool? Research has shown that, in heterosexual couples, women typically do the lion's share of household work, and this can lead them to opt-out of careers (Blair-Loy, 2003; Stone, 2008). It will be important for researchers to understand to what extent mandatory WFH orders amplify these gendered effects or, potentially, force couples to realize and revisit their uneven division of labor. Given that partners are known to play a key role in supporting (or undermining) each other’s careers and developing professional identities (Petriglieri \& Obodaru, 2019), it will also be key to understand how couples manage the emotional labor of dealing with anxiety provoked by the pandemic. Among interventions specific to families that researchers will want to want to understand more closely are the conditions and ways in which revisiting psychological contracts among couples - perhaps especially among couples with (young) children - is beneficial (Petriglieri, 2019).

Personality. The Big Five personality traits predict myriad work attitudes and behaviors, including those relevant to COVID-19, such as coping (Connor-Smith \& Flachsbart, 2007), work-life balance (Michel et al., 2011), and subjective well-being (Anglim et al., 2020). Secondorder quantitative reviews of 90+ meta-analyses show that Extraversion and Conscientiousness play particularly important roles in successful adjustment. Extraversion contributes to adjustment by promoting more frequent experiences of higher levels of positive emotion as well as a richer repertoire of interpersonal skill (Wilmot et al., 2019) whereas Conscientiousness contributes to adjustment by fostering commitment and perseverance toward more predictable, non-immediate work goals (Wilmot \& Ones, 2019). In light of this prior research, there are reasons to expect that both traits play key, yet distinct, roles in workplace adjustments to the pandemic. 
As COVID-19 can be conceptualized as a "strong situation,” which restricts the normal expression of personality, it therefore may act as a boundary condition of a traits’ typical predictive effects (Meyer et al., 2010). Two examples are relevant for future research and practice. First, in the short-term, the pandemic exerts situational constraints on an individuals' interpersonal behaviors via social distancing practices and lockdown orders. Experimental evidence shows that increasing introverted behaviors decreases positive emotions (Margolis \& Lyubomirsky, 2019). Thus, extraverts’ interpersonal and emotional advantages may be diminished, or reversed, by the strong, novel situation that is COVID-19. Indeed, lower levels of Extraversion (and Openness) are reported in countries that have historically suffered from higher levels of infectious diseases (Schaller \& Murray, 2008). Second, in the long-term, the pandemic exerts situational strength by introducing considerable unpredictability into individuals’ jobs. We know that Conscientiousness offers potent workplace benefits, but predictability facilitates its optimal expression. Unpredictability, on the other hand, increases job complexity, which, in turn, decreases Conscientiousness’ beneficial effects (Wilmot \& Ones, 2019). Accordingly, organizational interventions that bring role clarity and specific goals may offer much-needed predictability in an uncertain time. A focus on work goals and goal pursuit may eventually increase individuals’ experience of positive emotions (McCabe \& Fleeson, 2012).

Beyond the Big Five traits, other kinds of individual difference are likely to be important as well. With respect to WFH, for example, research by Rothbard et al. (2005) shows that "segmentors" tend to enjoy work and perform better when they are able to keep a clear boundary between work and non-work while "integrators" tend to prefer toggling between different activities and are less stressed by the commingling of work and non-work boundaries. Awareness of such variation is particularly valuable when WFH is required since people on either side of the 
spectrum will benefit from different adaptations - integrators will likely benefit from some segmenting (e.g,. of time and space) while segmentors - particularly if they are living with others - will need to better tolerate non-work interruptions when attempting to work.

Cultural differences. While cultural variation around the globe can be classified on numerous dimensions, the dimension of cultural tightness-looseness (TL), which is comparable to classifying cultures as relatively collectivist or individualist (Hofstede, 1984), appears most relevant for making sense of COVID-19 since it explains how human groups develop strong norms and tighter organizational cultures in reaction to life threatening-experiences (Harrington \& Gelfand, 2014). More specifically, prior research suggests that cultural tightening - with advantages that include greater social order, efficiency, and directive leadership - becomes more adaptive during a crisis, but is perhaps more maladaptive as recovery becomes timely and looseness and its associated creativity are needed. Historically, nations with more infectious disease threats are indeed culturally tighter and, as a result, less innovative in science and technology (Gelfand, 2019).

In anticipation of eventual recoveries from the COVID-19 shutdowns, organizations will need to find the right balance between an overly tight or loose culture, known as tight-loose ambidexterity (Gelfand, 2019). Accordingly, as many workplaces tighten in response to their shaky economic standing, successful organizations will benefit from having flexible tightness rules which bind employees together to prevent social isolation and loneliness, accompanied by the right dose of looseness, which affords employees latitude and autonomy where possible. It is clear that as the effective tightness or looseness of a given organization's culture changes as it deals with COVID-19, there will be associated changes in the ways that employees navigate other dimensions that we have examined in previous sections. For example, in culturally tight 
organizations (e.g., hospitals, airlines), team creativity and innovation may be fostered by allowing teams to interact virtually, whereas culturally looser organizations (e.g., universities) might profit from a greater concern with health and safety regulations, as a result of COVID-19.

Among other dimensions of cultural difference that are valuable to consider in relation to COVID-19, it is notable that just as research shows that infectious diseases can help cultivate political conservatism and xenophobia (Ji et al., 2019), it is logical to anticipate that sociocultural differences (e.g., in collectivism) help explain how people and organizations responded to COVID-19. While analysis of these kinds of cultural difference are outside of our scope, future research should consider whether and how more conservative employees and organizations have varied in their responses to COVID-19 when compared with more liberal others.

\section{Discussion and Conclusion}

For this project, we organized ourselves as a large and diverse virtual team of researchers to make sense of COVID-19's for questions of relevance to work and organizational psychology. As is known from prior research on teamwork among scientists (Kniffin \& Hanks, 2018), the benefits of this approach - since many hands make light work and many heads are better than a few - are obvious, especially as we are dealing with an urgent phenomenon, COVID-19, of seismic proportions. Nevertheless, it is also certain that our overview is limited and we may have missed some trends or developments that later turn out to be significant. Among the many current unknowns, we do not yet know how badly the global economy will be affected and how quickly it will recover. We also do not yet know if and when there will be a vaccine or effective medicine available nor how widely and quickly it will be distributed.

Notwithstanding the unknowns, it is obvious that COVID-19 will be recognized for changing the way we work in fundamental ways (see Table 1 for an overview of the 
implications, issues, and insights we have considered in this article). For example, COVID-19 abruptly accelerated the speed of changes associated with working outside of co-located offices. Virtual work practices are likely to spread as organizations realize the cost-savings from structuring labor with fewer full-time employees and more contractors connected technologically (Spreitzer, Cameron \& Garrett, 2017) - and perhaps with less office space in light of the health risks known to be associated with conventional open-plan offices (Pejtersen et al., 2011). The challenges for individuals working in this manner are clear: more of us will need to learn to work in ways far different than how people did in previous generations. In this respect, COVID-19 makes clear how vulnerable we are as employees and employers. As many businesses around the world will be restructured or disappear due to the pandemic, workers will be retrained or laid-off and the economic, social-psychological, and health costs of these actions are likely to be immense. Indeed, the impacts of the pandemic will affect some groups of workers more strongly than others, for example, based on their age, race and ethnicity, gender, or personality.

An understanding of how these abruptly emergent changes unfold is important for practitioners who are charting paths forward to address (e.g., with new interventions) the needs of vulnerable categories of employees. For instance, workers living alone may have very different virtual working needs and routines than employees living with family members. Also, more authoritarian or bossy leaders may face different challenges in motivating their workers in virtual environments than more participative and empathic team leaders, and thus have different training and development needs. Finally, in dealing with remote working populations, HR professionals must develop new performance management and appraisal systems while occupational health staff should be trained to recognize mental health issues in remote working populations - and be able to offer online advice and therapy. 
There are also many challenges for research. Our preview of questions that seem likely to become important should offer generalizability beyond the COVID-19 pandemic given that “extreme events” often provide windows into identifying and understanding dynamics that are important but not necessarily visible during normal conditions. We do not yet know what the long-term impact of social isolation and physical distancing protocols will have for employees. How will it affect job satisfaction and productivity? Research has focused almost exclusively on people who opted into WFH by choice, but mandatory and mass WFH is quite a different situation.

To consider the long-term effects, organizational researchers should perhaps also delve deeper into our history to learn about how epidemics and pandemics have been handled in the past. As Sir Winston Churchill once said: “The longer you can look back, the further you can look forward.” There are some parallels between the current crisis and previous threats such as WWII, the 9/11/2001 attacks, and the 2008 financial crisis. Yet COVID-19 is also unique since it is primarily a global health threat and thus requires a different set of adaptive responses (e.g., physical distancing instead of coming together). We therefore need theory development on how different kinds of global threats and crises shape workplaces in varied ways. We do know that infectious diseases have been a common aspect of human evolution and have shaped our psychology, behavior, and culture in surprising but predictable ways. As we now live and work in globally interdependent communities, infectious disease threats such as COVID-19 need to be recognized as part of the workscape. To continue to reap the benefits from global cooperation, we must find smarter and safer ways of working together. 
TABLE 1

Summary of Implications, Issues for Future Research, and Insights for Action regarding COVID-19 and the Workplace

\begin{tabular}{|c|c|c|c|}
\hline Domain of Work & Implications & Issues for Future Research & Insight-Driven Actions \\
\hline \multicolumn{4}{|c|}{ Emergent Changes in Work Practices } \\
\hline $\begin{array}{l}\text { Work From } \\
\text { Home (WFH) }\end{array}$ & $\begin{array}{l}\text { The massive, abrupt, and } \\
\text { mandatory (for many } \\
\text { employees) switch to work } \\
\text { from home (WFH) has } \\
\text { required employees to adapt } \\
\text { while employers have become } \\
\text { more open to adopting the } \\
\text { practice post-pandemic. }\end{array}$ & $\begin{array}{l}\text { How will WFH policies affect } \\
\text { employee attitudes and behaviors to } \\
\text { their employers as well as their co- } \\
\text { workers? } \\
\text { How will employee attitudes to } \\
\text { privacy and monitoring shift for } \\
\text { work that is done outside of an } \\
\text { office setting? }\end{array}$ & $\begin{array}{l}\text { Employees should create rituals that } \\
\text { allow tranisitions (in the absence of } \\
\text { commuting) in order to manage the } \\
\text { boundaries between work and home. } \\
\text { Organizations should adopt and } \\
\text { encourage routines that enhance trust } \\
\text { while being attentive to the costs of } \\
\text { increased monitoring. }\end{array}$ \\
\hline Virtual Teams & $\begin{array}{l}\text { Employees who are forced to } \\
\text { work virtually for team } \\
\text { projects have needed to } \\
\text { navigate the indirect and } \\
\text { direct conflicts that can result } \\
\text { in performance losses. }\end{array}$ & $\begin{array}{l}\text { How will emotion expression and } \\
\text { communication in teams with either } \\
\text { low or high virtuality affect } \\
\text { outcomes? } \\
\text { What factors will lead to helping and } \\
\text { prosocial behaviors in teams with } \\
\text { either low or high virtuality - and } \\
\text { how will these impact outcomes? }\end{array}$ & $\begin{array}{l}\text { Team members need to pay attention } \\
\text { to the structure and nature of } \\
\text { communication flows in order to } \\
\text { manage them effectively. } \\
\text { Organizations should provide } \\
\text { opportunities for non-task interactions } \\
\text { among employees to allow emotional } \\
\text { connections and bonding to continue } \\
\text { among team members. }\end{array}$ \\
\hline $\begin{array}{l}\text { Virtual } \\
\text { Leadership and } \\
\text { Management }\end{array}$ & $\begin{array}{l}\text { Leaders are tested when } \\
\text { presented with systemic } \\
\text { shocks and must continue to } \\
\text { project vision. Managers are } \\
\text { faced with new challenges to } \\
\text { supervise and cultivate the }\end{array}$ & $\begin{array}{l}\text { How will leaders adapt their styles } \\
\text { in response to shocks such as the } \\
\text { current pandemic? } \\
\text { How can organizations create } \\
\text { superior leader communication to }\end{array}$ & $\begin{array}{l}\text { Leaders need to balance optimism } \\
\text { and realism in their communications } \\
\text { with employees while demonstrating } \\
\text { skills such as charisma. }\end{array}$ \\
\hline
\end{tabular}




\begin{tabular}{|c|c|c|c|}
\hline & $\begin{array}{l}\text { development of their } \\
\text { subordinates from much } \\
\text { greater distance than usual. }\end{array}$ & $\begin{array}{l}\text { allow feedback and mentoring to } \\
\text { happen effectively? }\end{array}$ & $\begin{array}{l}\text { Organizations need to (continue to) } \\
\text { invest in the development of current } \\
\text { and potential leaders to build new } \\
\text { skills to function effectively in new } \\
\text { work settings. }\end{array}$ \\
\hline \multicolumn{4}{|c|}{ Economic and Social-Psychological Impacts } \\
\hline $\begin{array}{l}\text { Unemployment } \\
\text { and Layoffs }\end{array}$ & $\begin{array}{l}\text { The costs of unemployment } \\
\text { are both economic and latent } \\
\text { due to the loss of social } \\
\text { structure, status, and social } \\
\text { ties. There are also direct and } \\
\text { indirect costs experienced by } \\
\text { those who remain working in } \\
\text { organizations that have laid } \\
\text { off workers. }\end{array}$ & $\begin{array}{l}\text { What is the impact of } \\
\text { unemployment beyond mental } \\
\text { health outcomes and how can the } \\
\text { unemployed recover? } \\
\text { What HR practices, policies, } \\
\text { programs, and/or forms of support } \\
\text { can alleviate the negative } \\
\text { consequences of mass layoffs on } \\
\text { those who remain employed? }\end{array}$ & $\begin{array}{l}\text { Job searching requires resilience and } \\
\text { persistence and job seekers should } \\
\text { seek support and information from } \\
\text { others. } \\
\text { Job seekers should also prepare for a } \\
\text { longer job search than would be the } \\
\text { case with lower unemployment rates. }\end{array}$ \\
\hline Presenteeism & $\begin{array}{l}\text { Among people serving } \\
\text { "essential” jobs, there is } \\
\text { likely to be an increase in } \\
\text { people going to work when } \\
\text { ill. }\end{array}$ & $\begin{array}{l}\text { How can employer pay and benefit } \\
\text { plans best be structured to } \\
\text { discourage people going to work } \\
\text { when ill? }\end{array}$ & $\begin{array}{l}\text { Employers should not incentivize } \\
\text { employees to work through illness. } \\
\text { Leaders should model appropriate } \\
\text { behaviour and not attend work when } \\
\text { ill. }\end{array}$ \\
\hline $\begin{array}{l}\text { Economic } \\
\text { Inequality }\end{array}$ & $\begin{array}{l}\text { Increases in inequality } \\
\text { expected from the shock of } \\
\text { COVID-19 is likely to lead to } \\
\text { burnout, deviant behaviors, } \\
\text { and withdrawals. }\end{array}$ & $\begin{array}{l}\text { How can organizations best } \\
\text { minimize the individual and } \\
\text { organizational costs of broader } \\
\text { social inequality? }\end{array}$ & $\begin{array}{l}\text { Organizations need to reduce } \\
\text { inequalities, by reducing selection } \\
\text { biases in favour of the } \\
\text { demographically privileged and } \\
\text { taking action to prevent further } \\
\text { negative spiraling of pay and benefits. }\end{array}$ \\
\hline $\begin{array}{l}\text { Social Distancing } \\
\text { and Loneliness }\end{array}$ & $\begin{array}{l}\text { WFH - and the re- } \\
\text { organization of workspaces to } \\
\text { ensure distance among people }\end{array}$ & $\begin{array}{l}\text { How can organizations foster high- } \\
\text { quality social interactions among co- }\end{array}$ & $\begin{array}{l}\text { HR communications should } \\
\text { acknowledge the risk of workplace } \\
\text { loneliness and the value of social }\end{array}$ \\
\hline
\end{tabular}




\begin{tabular}{|c|c|c|c|}
\hline & $\begin{array}{l}\text { - is likely to hamper social } \\
\text { connections and, in turn, } \\
\text { negatively affect employee } \\
\text { mental and physical health. }\end{array}$ & $\begin{array}{l}\text { workers when WFH or working in } \\
\text { de-densified workplaces? } \\
\text { What innovations are most effective } \\
\text { for mitigating an increase in } \\
\text { loneliness? }\end{array}$ & $\begin{array}{l}\text { connections as part of broader } \\
\text { employee wellness programming. } \\
\text { Organizations should identify and } \\
\text { implement policies and interventions } \\
\text { to support social connections among } \\
\text { employees. }\end{array}$ \\
\hline $\begin{array}{l}\text { Stress and } \\
\text { Burnout }\end{array}$ & $\begin{array}{l}\text { Increased job demands and } \\
\text { reduced resources are likely } \\
\text { to lead to greater stress } \\
\text { among employees. }\end{array}$ & $\begin{array}{l}\text { Does rumination about a major crisis } \\
\text { like COVID-19 exacerbate the stress } \\
\text { and preclude effective use of the } \\
\text { available job resources? }\end{array}$ & $\begin{array}{l}\text { Leaders should be trained to facilitate } \\
\text { job crafting so that employees can } \\
\text { better cope with new and uncertain } \\
\text { job demands. }\end{array}$ \\
\hline Addiction & $\begin{array}{l}\text { Increase in substance misuse } \\
\text { is possible during the } \\
\text { pandemic and any subsequent } \\
\text { economic downturn. }\end{array}$ & $\begin{array}{l}\text { What is the efficacy of internet- } \\
\text { based, brief interventions in } \\
\text { preventing the onset and/or } \\
\text { exacerbation of alcohol misuse } \\
\text { among employees? } \\
\text { What is the impact of the relaxation } \\
\text { of COVID restrictions/return to } \\
\text { work on alcohol misuse and } \\
\text { addictions more generally? }\end{array}$ & $\begin{array}{l}\text { With appropriate consent and } \\
\text { attention to privacy issues, } \\
\text { organizations should invest in } \\
\text { machine learning and wearable } \\
\text { technologies designed to virtually and } \\
\text { rapidly identify the onset or } \\
\text { exacerbation of risky behaviors such } \\
\text { as alcohol misuse. }\end{array}$ \\
\hline \multicolumn{4}{|c|}{ Moderating Factors } \\
\hline Age & $\begin{array}{l}\text { Older employees face } \\
\text { disparate health and economic } \\
\text { risks related to COVID-19 } \\
\text { with impacts on retirement } \\
\text { planning. }\end{array}$ & $\begin{array}{l}\text { How will organizations respond to } \\
\text { age-specific concerns involving the } \\
\text { risks associated with COVID-19? }\end{array}$ & $\begin{array}{l}\text { Organizations should intervene to } \\
\text { simultaneously (a) optimize employee } \\
\text { human capital across the lifespan and } \\
\text { (b) strengthen internal labor markets } \\
\text { (e.g., through cross-age mentoring). }\end{array}$ \\
\hline $\begin{array}{l}\text { Race and } \\
\text { Ethnicity }\end{array}$ & $\begin{array}{l}\text { Members of racial and ethnic } \\
\text { minority groups face } \\
\text { disparate health and } \\
\text { economics risks related to } \\
\text { COVID-19. }\end{array}$ & $\begin{array}{l}\text { How do organizationas foster } \\
\text { inclusion and a sense of belonging } \\
\text { among racial and ethnic minorities } \\
\text { when the economy is uncertain and } \\
\text { the threat of job loss is high? }\end{array}$ & $\begin{array}{l}\text { Employers need to create an } \\
\text { environment where all employees, } \\
\text { including racial and ethnic minorities, } \\
\text { realize how they can contribute to the } \\
\text { organization's goals. }\end{array}$ \\
\hline
\end{tabular}




\begin{tabular}{|c|c|c|c|}
\hline Gender & $\begin{array}{l}\text { Men are more likely to face } \\
\text { direct health threats of } \\
\text { COVID-19. Women are more } \\
\text { likely to be affected by the } \\
\text { adverse economic and social } \\
\text { costs. }\end{array}$ & $\begin{array}{l}\text { What is the value of feminine } \\
\text { leadership styles in extreme crisis } \\
\text { management, despite the } \\
\text { documented preference for } \\
\text { masculine leaders under crisis? }\end{array}$ & $\begin{array}{l}\text { Greater value should be placed on } \\
\text { alternatives to more masculine } \\
\text { leadership styles that seem to be } \\
\text { effective in relation to COVID- } 19 \text {. }\end{array}$ \\
\hline Family Status & $\begin{array}{l}\text { Working parents with school- } \\
\text { age children face disparate } \\
\text { WFH challenges, especially } \\
\text { when schools are closed. }\end{array}$ & $\begin{array}{l}\text { Will mandatory WFH and "School } \\
\text { From Home” disadvantage working } \\
\text { mothers more than working fathers? }\end{array}$ & $\begin{array}{l}\text { Working couples should } \\
\text { communicate openly about how they } \\
\text { divide household labor and childcare. }\end{array}$ \\
\hline Personality & $\begin{array}{l}\text { Differential impact of social } \\
\text { distancing and work from } \\
\text { home for those high on } \\
\text { Extraversion and } \\
\text { Conscientiousness compared } \\
\text { to those who are lower. } \\
\text { Other individual differences } \\
\text { will also be important such as } \\
\text { segmentors and integrators } \\
\text { struggling with WFH. }\end{array}$ & $\begin{array}{l}\text { How do personality traits - in } \\
\text { particular, Extraversion and } \\
\text { Conscientiousness - function in } \\
\text { response to the "strong situation" } \\
\text { represented by COVID-19? } \\
\text { How will the pandemic diminish - } \\
\text { or even reverse - the advantageous } \\
\text { work relations typically associated } \\
\text { with Extraversion and } \\
\text { Conscientiousness? }\end{array}$ & $\begin{array}{l}\text { Organizations should strive to reduce } \\
\text { unpredictability (i.e., providing } \\
\text { clarity to job roles and work goals) to } \\
\text { help restore the benefits of traits such } \\
\text { as Conscientiousness. } \\
\text { "Segmentors" will need to tolerate } \\
\text { non-work interruptions when working } \\
\text { while "Integrators" will benefit from } \\
\text { some segmenting of time and space. }\end{array}$ \\
\hline $\begin{array}{l}\text { Cultural } \\
\text { Differences }\end{array}$ & $\begin{array}{l}\text { Norms will tend to be } \\
\text { stronger and less flexible, } \\
\text { leading to a greater tightness } \\
\text { of organizational cultures, } \\
\text { when the threat of infection is } \\
\text { high. As the perceived threat } \\
\text { of infection lowers, there will } \\
\text { be a corresponding loosening } \\
\text { of norms. }\end{array}$ & $\begin{array}{l}\text { How do organizations effectively } \\
\text { tighten and loosen (or "close" and } \\
\text { "open") in response to systemic } \\
\text { shocks? }\end{array}$ & $\begin{array}{l}\text { Leaders need to understand how to be } \\
\text { ambidextrous regarding social norms, } \\
\text { knowing when to deploy tightness } \\
\text { and looseness as needed since the } \\
\text { former offers protection and the latter } \\
\text { facilitates creativity and innovation. }\end{array}$ \\
\hline
\end{tabular}




\section{References}

Allen, T. D., Cho, E., \& Meier, L. L. (2014). Work-family boundary dynamics. Annual Review of Organizational Psychology and Organizational Behavior, 1(1), 99-121.

Allen, T. D., Golden, T. D., \& Shockley, K. M. (2015). How effective is telecommuting? Assessing the status of our scientific findings. Psychological Science in the Public Interest, 16(2), 40-68.

Alon, T. M., Doepke, M., Olmstead-Rumsey, J., \& Tertilt, M. (2020). The Impact of covid-19 on gender equality. National Bureau of Economic Research.

Anglim, J., Horwood, S., Smillie, L. D., Marrero, R. J., \& Wood, J. K. (2020). Predicting psychological and subjective well-being from personality: A meta-analysis. Psychological Bulletin, 146(4), 279-323.

Antonakis, J., \& Day, D. V. (2017). Leadership: Past, present, and future. In J. Antonakis \& D. Day (Eds.), The nature of leadership ( $3^{\text {rd }}$ ed.), p. 56-81. Thousand Oaks: Sage Publications.

Antonakis, J., \& Atwater, L. (2002). Leader distance: A review and a proposed theory. The Leadership Quarterly, 13(6), 673-704.

Antonakis, J., Bastardoz, N., Jacquart, P., \& Shamir, B. (2016). Charisma: An ill-defined and illmeasured gift. Annual Review of Organizational Psychology and Organizational Behavior, 3, 293-319.

Ashford, S. J., Caza, B. B., \& Reid, E. M. (2018). From surviving to thriving in the gig economy: A research agenda for individuals in the new world of work. Research in Organizational Behavior, 38, 23-41..

Bacharach, S. B., Bamberger, P. A., \& Sonnenstuhl, W.J. (2002). Driven to drink: Managerial control, work-related risk factors, and employee problem drinking. Academy of Management Journal, 45(4), 637-658.

Bakker, A.B., \& Demerouti, E. (2017). Job Demands-Resources theory: Taking stock and looking forward. Journal of Occupational Health Psychology, 22, 273-285.

Bamberger, P., \& Bacharach, S. B. (2014). Retirement and the Hidden Epidemic: The Complex Link Between Aging, Work Disengagement, and Substance Misuse - and what to Do about it. Oxford University Press.

Bapuji, H., Ertug, G., \& Shaw, J. D. (2020). Organizations and societal economic inequality: a review and way forward. Academy of Management Annals, 14(1), 60-91.

Baumeister, R. F., \& Leary, M. R. (1997). Writing narrative literature reviews. Review of General Psychology, 1(3), 311-320 
Bhagat, R. S. (1983). Effects of stressful life events on individual performance effectiveness and work adjustment processes within organizational settings: A research model. Academy of Management Review, 8(4), 660-671.

Bhave, D.P., Teo, L.H., \& Dalal, R.S. (2020). Privacy at work: A review and a research agenda for a contested terrain. Journal of Management, 46, 127-164.

Ben-Porath, D. D. (2002). Stigmazation of individuals who receive psychotherapy: An interaction between help-seeking behavior and the presence of depression. Journal of Social and Clinical Psychology, 21(4), 400-413.

Blair-Loy, M. (2009). Competing devotions: Career and family among women executives. Harvard University Press.

Bloise, S. M., \& Johnson, M. K. (2007). Memory for emotional and neutral information: Gender and individual differences in emotional sensitivity. Memory, 15(2), 192-204.

Bohns, V. \& Flynn, F. (2010). “Why didn’t you ask?” Overestimating the willingness to seek help and underestimating discomfort in help-seeking. Journal of Experimental Social Psychology, 46, 402-409.

Brendryen, H., Johansen, A., Duckert, F., \& Nesvåg, S. (2017). A pilot randomized controlled trial of an internet-based alcohol intervention in a workplace setting. International Journal of Behavioral Medicine, 24(5), 768-777.

Brooke, L., \& Taylor, P. (2005). Older workers and employment: managing age relations. Ageing \& Society, 25(3), 415-429. doi: 10.1017/S0144686X05003466

Brooks, S. K., Webster, R. K., Smith, L. E., Woodland, L., Wessely, S., Greenberg, N., \& Rubin, G. J. (2020). The psychological impact of quarantine and how to reduce it: Rapid review of the evidence. Lancet, 395, 912-920.

Cacioppo, J. T., Hawkley, L. C., Ernst, J. M., Burleson, M., Berntson, G. G., Nouriani, B., \& Spiegel, D. (2006). Loneliness within a nomological net: An evolutionary perspective. Journal of Research in Personality, 40, 1054-1085.

Campbell, A. (2013). A mind of her own: The evolutionary psychology of women. Oxford University Press.

Cleavenger, D., \& Munyon, T. (2015). Overcoming the help-seeker's dilemma: How computermediated systems encourage employee help-seeking initiation. Organization Studies, 36(2), 221-240.

Combe, I. A., \& Carrington, D. J. (2015). Leaders’ sensemaking under crises: Emerging cognitive consensus over time within management teams. The Leadership Quarterly, 26, 307-322. 
Connor-Smith, J. K., \& Flachsbart, C. (2007). Relations between personality and coping: A meta-analysis. Journal of Personality and Social Psychology, 93(6), 1080-1107.

Cook, T., Kursumovic, E., \& Lennane, S. (2020). Exclusive: deaths of NHS staff from covid-19 analysed. Health Service Journal. Last accessed May 8, 2020 at:

https://www.hsj.co.uk/exclusive-deaths-of-nhs-staff-from-covid-19analysed/7027471.article

Cookson, C. \& Milne, R. (2020). Nations look into why coronavirus hits ethnic minorities so hard. Financial Times. Last accessed April 29, 2020 at: https://www.ft.com/content/5fd6ab18-be4a-48de-b887-8478a391dd72

Creary, S. J., Caza, B. B., \& Roberts, L. M. (2015). Out of the box? How managing a subordinate's multiple identities affects the quality of a manager-subordinate relationship. Academy of Management Review, 40(4), 538-562.

Demerouti, E., Mostert, K., \& Bakker, A. B. (2010). Burnout and work engagement: a thorough investigation of the independency of both constructs. Journal of Occupational Health Psychology, 15(3), 209-222.

DeRosa, D. M., Smith, C. L., \& Hantula, D. A. (2007). The medium matters: Mining the longpromised merit of group interaction in creative idea generation tasks in a meta-analysis of the electronic group brainstorming literature. Computers in Human Behavior, 23(3), 15491581.

Diamond, J. M. (1998). Guns, Germs, and Steel: A short history of everybody for the last 13,000 years. Random House.

Dietz, C., Zacher, H., Scheel, T., Otto, K. \& Rigotti, T. (2020). Leaders as role models: Effects of leader presenteeism on employee presenteeism and sick leave. Work \& Stress. In Press.

Dunbar, R. I. (2018). The anatomy of friendship. Trends in Cognitive Sciences, 22(1), 32-51.

Eckel, C. C., \& Grossman, P. J. (2008). Men, women and risk aversion: Experimental evidence. In C. Plott \& V. Smith (Eds.), Handbook of Experimental Economics Results (Vol. 1, pp. 1061-1073). Elsevier.

Eisenberg, N., \& Lennon, R. (1983). Sex differences in empathy and related capacities. Psychological Bulletin, 94(1), 100-131

Elvira, M. M., \& Zatzick, C. D. (2002). Who’s displaced first? The role of race in layoff decisions. Industrial Relations: A Journal of Economy and Society, 41(2), 329-361.

Flynn, F. J., \& Lake, V. K. (2008). If you need help, just ask: Underestimating compliance with direct requests for help. Journal of Personality and Social Psychology, 95(1), 128-143. 
Flynn, J., Slovic, P., \& Mertz, C. K. (1994). Gender, race, and perception of environmental health risks. Risk Analysis, 14(6), 1101-1108.

Gartner. (2020). Gartner HR Survey Reveals 41\% of Employees Likely to Work Remotely at Least Some of the Time Post Coronavirus Pandemic. News Release, April 14.

Gelfand, M. (2019). Rule Makers, Rule Breakers: Tight and Loose Cultures and the Secret Signals That Direct Our Lives. Scribner.

Gibson, C. B., \& Gibbs, J. L. (2006). Unpacking the concept of virtuality: The effects of geographic dispersion, electronic dependence, dynamic structure, and national diversity on team innovation. Administrative Science Quarterly, 51(3), 451-495.

Gillespie, P. (2017). Intuit: Gig economy is 34\% of US workforce. CNN. Retrieved from: https://money.cnn.com/2017/05/24/news/economy/gig-economy-intuit/index.

Gilligan, C. (1982). In a Different Voice: Psychological theory and women's development. Harvard University Press.

Golan, M., Bacharach, Y., \& Bamberger, P. (2010). Peer assistance programs in the workplace. In J. Houdmont \& S. Leka (Eds.), Contemporary occupational health psychology: Global perspectives on research and practice, volume 1 (pp. 169-187). John Wiley \& Sons Ltd.

Good, C., Rattan, A., \& Dweck, C. S. (2012). Why do women opt out? Sense of belonging and women's representation in mathematics. Journal of Personality and Social Psychology, 102(4), 700-717.

Grabo, A., Spisak, B. R., \& van Vugt, M. (2017). Charisma as signal: An evolutionary perspective on charismatic leadership. The Leadership Quarterly, 28(4), 473-485.

Grant, B. F., Chou, S. P., \& Saha, T. D., Pickering, R. P., Kerridge, B. T., Huang, B., Jung, J., Zhang, H., Fan, A., \& Hasin, D. S. (2017). Prevalence of 12-month alcohol use, high-risk drinking, and DSM-IV alcohol use disorder in the United States, 2001-2002 to 2012-2013: Results from the National Epidemiologic Survey on alcohol and related conditions. JAMA Psychiatry, 74(9), 911-923.

Harrington, J. R., \& Gelfand, M. J. (2014). Tightness-looseness across the 50 united states. Proceedings of the National Academy of Sciences, 111(22), 7990-7995.

Hirsh, C. E., \& Kornrich, S. (2008). The context of discrimination: Workplace conditions, institutional environments, and sex and race discrimination charges. American Journal of Sociology, 113(5), 1394-1432.

Hoch, J. E., \& Kozlowski, S. W. (2014). Leading virtual teams: Hierarchical leadership, structural supports, and shared team leadership. Journal of Applied Psychology, 99(3), 390403. 
Hofstede, G. (1984). Culture's Consequences: International differences in work-related values (Vol. 5). New York, NY: Sage.

Huang, W. W., Wei, K. K., Watson, R. T., \& Tan, B. C. Y. (2002). Supporting virtual teambuilding with a GSS: An empirical investigation. Decision Support Systems, 34, 359-367.

IJzerman, H., Lewis Jr, N., Weinstein, N., DeBruine, L., Ritchie, S. J., Vazire, S., ... \& Przybylski, A. K. (2020). Psychological Science Is Not yet a Crisis-ready Discipline. https://doi.org/10.31234/osf.io/whds4

Imai, C., Hall, L., Lambert, S.B., \& Merollini, K.M.D. (2020). Presenteeism among health care workers with laboratory-confirmed influenza infection: A retrospective cohort study in Queensland, Australia. American Journal of Infection Control, 48, 355-360.

IPPR. (2020). Institute for Public Policy Research (IPPR): 2020 Covid-19 Survey on Health Workers in the UK. https://www.ippr.org/news-and-media/press-releases/covid-19-one-infive-healthcare-workers-could-quit-after-pandemic-unless-urgent-government-action-istaken-ippr-warns.

Jahoda, M. (1982). Employment and Unemployment: A Social-Psychological Analysis. Cambridge University Press

Ji, T., Tybur, J. M., \& van Vugt, M. (2019). Generalized or origin-specific out-group prejudice?: the role of temporary and chronic pathogen-avoidance motivation in intergroup relations. Evolutionary Psychology, 17(1), 1474704919826851.

Johns, G. (2010). Presenteeism in the workplace: A review and research agenda. Journal of Organizational Behavior, 31, 519-542. https://doi.org/10.1002/job.630

Katz, L. F., \& Krueger, A. B. (2016). The rise and nature of alternative work arrangements in the United States, 1995-2015 (No. w22667). National Bureau of Economic Research.

Kessler, R. C., \& McLeod, J. D. (1984). Sex differences in vulnerability to undesirable life events. American Sociological Review, 49(5), 620-631.

Kessler, S. (2017, April 19). Amazon is using peer pressure to keep German warehouse workers from calling in sick. Quartz. Retrieved from https:/qz.com/962717/ amazon-pays-germanwarehouse-workers-bonuses-partly-based-on-when-their-coworkers-call-in-sick/

Klehe, U. C., Zikic, J., van Vianen, A. E., Koen, J., \& Buyken, M. (2012). Coping proactively with economic stress: Career adaptability in the face of job insecurity, job loss, unemployment, and underemployment. The Role of the Economic Crisis on Occupational Stress and Well Being, 10, 131-176

Kniffin, K. M., \& Hanks, A. S. (2018). The trade-offs of teamwork among STEM doctoral graduates. American Psychologist, 73(4), 420-432. 
Lindebaum, D., Geddes, D., \& Jordan, P. J. (editors) (2018). Social Functions of Emotion and Talking About Emotion at Work. Edward Elgar Publishing.

Mak, S., \& Kozlowski, S. W. J. (2019). Virtual teams: Conceptualization, integrative review, and research recommendations. In R. Landers, (Ed.), The Cambridge handbook of technology and employee behavior. Cambridge, UK. The Cambridge University Press

Margolis, S., \& Lyubomirsky, S. (2020). Experimental manipulation of extraverted and introverted behavior and its effects on well-being. Journal of Experimental Psychology: General, 149(4), 719-731.

Martins, L. L., Gilson, L. L., \& Maynard, M. T. (2004). Virtual teams: What do we know and where do we go from here?. Journal of Management, 30(6), 805-835.

McCabe, K. O., \& Fleeson, W. (2012). What is extraversion for? Integrating trait and motivational perspectives and identifying the purpose of extraversion. Psychological Science, 23(12), 1498-1505.

McDermott, R., Cheng, H., Wong, J., Booth, N., Jones, Z., \& Sevig, T. (2017). Hope for helpseeking: A positive psychology perspective of psychological help-seeking intentions. The Counseling Psychologist, 1-29.

McKee-Ryan, F. M., \& Maitoza, R. (2018). Job Loss, unemployment, and families. In The Oxford Handbook of Job Loss and Job Search, ed. UC Klehe, EAJ van Hooft, pp. 259-74. New York: Oxford University Press.

McKinsey \& Co (2016). Independent work: Choice, necessity, and the gig economy. McKinsey Global Institute.

Meyer, R. D., Dalal, R. S., \& Hermida, R. (2010). A review and synthesis of situational strength in the organizational sciences. Journal of Management, 36(1), 121-140.

Michel, J. S., Kotrba, L. M., Mitchelson, J. K., Clark, M. A., \& Baltes, B. B. (2011). Antecedents of work-family conflict: A meta-analytic review. Journal of Organizational Behavior, 32(5), 689-725.

Mikos, M., Juszczyk, G., Czerw, A., Strzępek, Ł., Banaś, T., Cipora, E., Deptała, A., \& Badowska-Kozakiewicz, A. (2020). Refusal to take sick leave after being diagnosed with a communicable disease as an estimate of the phenomenon of presenteeism in Poland. Medical Principles and Practice, 29, 134-141.

Miraglia, M., \& Johns, G. (2016). Going to work ill: A meta-analysis of the correlates of presenteeism and a dual-path model. Journal of Occupational Health Psychology, 21, 261283. 
Mogilner, C., Whillans, A., \& Norton, M. I. (2018). Time, money, and subjective wellbeing. In E. Diener, S. Oishi, \& L. Tay (Eds.), Handbook of Well-Being. Noba Scholar Handbook series: Subjective well-being. DEF publishers.

Mortensen, M., \& Hinds, P. J. (2001). Conflict and shared identity in geographically distributed teams. International Journal of Conflict Management, 12, 212-238.

Murthy, V. (2017). Work and the loneliness epidemic: reducing isolation at work is good business. Harvard Business Review. Retrieved from https://hbr.org/coverstory/2017/09/work-and-the-loneliness-epidemic.

Newark, D., Bohns, V., \& Flynn, F. (2017). A helping hand is hard at work: Underestimating help quality. Organizational Behavior and Human Decision Processes, 139, 223-226.

Nell, P. C., Foss, N. J., Klein, P. G., \& Schmitt, J.. (2020). Avoiding Digitalization Traps: Tools for Top Managers. Business Horizons, in press.

New York City Department of Health and Mental Hygiene (2020). Age adjusted rate of fatal lab confirmed COVID-19 cases per 100,000 by race/ethnicity group. Last accessed on April 29, 2020 at: https://www1.nyc.gov/assets/doh/downloads/pdf/imm/covid-19-deaths-raceethnicity-04082020-1.pdf

New York City Office of the Comptroller (2020). New York City's frontline workers. Bureau of Policy and Research. Last accessed on April 29, 2020 at: https:/comptroller.nyc.gov/wpcontent/uploads/documents/Frontline_Workers_032020.pdf

Nkomo, S., \& Hoobler, J. M. (2014). A historical perspective on diversity ideologies in the United States: Reflections on human resource management research and practice. Human Resource Management Review, 24(3), 245-257.

Nolen-Hoeksema, S., Wisco, B. E., \& Lyubomirsky, S. (2008). Rethinking rumination. Perspectives on Psychological Science, 3, 400-424.

Obradovich, N., Migliorini, R., Paulus, M. P., \& Rahwan, I. (2018). Empirical evidence of mental health risks posed by climate change. Proceedings of the National Academy of Sciences, 115(43), 10953-10958.

Oprea, B. T., Barzin, L., Vîrgă, D., Iliescu, D., \& Rusu, A. (2019). Effectiveness of job crafting interventions: a meta-analysis and utility analysis. European Journal of Work and Organizational Psychology, 28(6), 723-741.

Ozcelik, H., and Barsade, S. (2018). No employee an island: Workplace loneliness and employee performance. Academy of Management Journal, 61(6), 2343-2366.

Park, T. Y., \& Shaw, J. D. (2013). Turnover rates and organizational performance: A metaanalysis. Journal of Applied Psychology, 98, 268-309. 
Paustian-Underdahl, S. C., King, E. B., Rogelberg, S. G., Kulich, C., \& Gentry, W. A. (2017). Perceptions of supervisor support: Resolving paradoxical patterns across gender and race. Journal of Occupational and Organizational Psychology, 90, 436-457.

Pejtersen, J. H., Feveile, H., Christensen, K. B., \& Burr, H. (2011). Sickness absence associated with shared and open-plan offices-a national cross sectional questionnaire survey. Scandinavian Journal of Work, Environment \& Health, 37, 376-382.

Petriglieri, G., Ashford, S. J., \& Wrzesniewski, A. (2019). Agony and ecstasy in the gig economy: Cultivating holding environments for precarious and personalized work identities. Administrative Science Quarterly, 64(1), 124-170.

Petriglieri, J. L. (2019). Couples That Work: How dual-career couples can thrive in love and work. Harvard Business Review Press.

Petriglieri, J. L., \& Obodaru, O. (2019). Secure-base relationships as drivers of professional identity development in dual-career couples. Administrative Science Quarterly, 64(3), 694736.

Pichler, S., \& Ziebarth, N.R. (2017). The pros and cons of sick pay schemes: Testing for contagious presenteeism and noncontagious absenteeism behavior. Journal of Public Economics, 156, 14-33.

Popovici, I., \& French, M. T. (2013). Does unemployment lead to greater alcohol consumption? Industrial Relations: A Journal of Economy and Society, 52(2), 444-466.

Pritchard, R. D., Harrell, M. M., DiazGranados, D., \& Guzman, M. J. (2008). The productivity measurement and enhancement system: a meta-analysis. Journal of Applied Psychology, 93(3), 540. https://doi.org/10.1037/0021-9010.93.3.540.

Ramarajan, L., \& Reid, E. (2013). Shattering the myth of separate worlds: Negotiating nonwork identities at work. Academy of Management Review, 38(4), 621-644.

Roberts, L. M., Mayo, A. J., \& Thomas, D. A. (2019). Race, Work, and Leadership. Harvard Business Review Press: Boston.

Rothbard, N. P., Phillips, K. W., \& Dumas, T. L. (2005). Managing multiple roles: Work-family policies and individuals’ desires for segmentation. Organization Science, 16(3), 243-258.

Rudolph, C. W., Marcus, J., \& Zacher, H. (2018). Global issues in work, aging and retirement. In K. Schultz \& G. Adams (Eds.), Aging and work in the 21 st century (2 ${ }^{\text {nd }}$ ed), p. 292-324.

Rudolph, C. W., \& Zacher, H. (2020). “The COVID-19 generation”: A cautionary note. Work, Aging \& Retirement. doi: 10.1093/workar/waaa009 
Schaller, M., \& Murray, D. R. (2008). Pathogens, personality, and culture: Disease prevalence predicts worldwide variability in sociosexuality, extraversion, and openness to experience. Journal of Personality and Social Psychology, 95(1), 212-221.

Schmitt, D. P., Realo, A., Voracek, M., \& Allik, J. (2008). Why can't a man be more like a woman? Sex differences in Big Five personality traits across 55 cultures. Journal of Personality and Social Psychology, 94(1), 168-182.

Schroeder, J., Risen, J. L., Gino, F., \& Norton, M. I. (2019). Handshaking promotes deal-making by signaling cooperative intent. Journal of Personality and Social Psychology, 116(5), 743-768.

Sine, W. D., \& David, R. J. (2003). Environmental jolts, institutional change, and the creation of entrepreneurial opportunity in the US electric power industry. Research Policy, 32(2), 185207.

Sirola, N., \& Pitesa, M. (2017). Economic downturns undermine workplace helping by promoting a zero-sum construal of success. Academy of Management Journal, 60(4), 13391359.

Smith, A. N., Watkins, M. B., Ladge, J. J., \& Carlton, P. (2019). Making the Invisible Visible: Paradoxical Effects of Intersectional Invisibility on the Career Experiences of Executive Black Women. Academy of Management Journal, 62(6), 1705-1734.

Spicer, R. S., \& Miller, T. R. (2005). Impact of a workplace peer-focused substance abuse prevention and early intervention program. Alcoholism: Clinical and Experimental Research, 29(4), 609-611.

Stoker, J. I., Garretsen, H., \& Soudis, D. (2019). Tightening the leash after a threat: A multi-level event study on leadership behavior following the financial crisis. The Leadership Quarterly, 30(2), 199-214.

Stone, P. (2008). Opting out?: Why women really quit careers and head home. University of California Press.

Tinghög, G., Andersson, D., Bonn, C., Johannesson, M., Kirchler, M., Koppel, L., \& Västfjäll, D. (2016). Intuition and moral decision-making-the effect of time pressure and cognitive load on moral judgment and altruistic behavior. PloS one, 11(10), 1-19

Trevor, C. O., \& Nyberg, A. J. 2008. Keeping your headcount when all about you are losing theirs: Downsizing, voluntary turnover rates, and the moderating role of HR practices. Academy of Management Journal, 51, 259-276.

Van Bavel, J. J., Boggio, P., Capraro, V., Cichocka, A., Cikara, M., Crockett, M., ... \& Ellemers, N. (2020). Using social and behavioural science to support COVID-19 pandemic response. Nature Human Behavior. 
Vandenberghe, C., Landry, G., Bentein, K., Anseel, F., Mignonac, K., \& Roussel, P. (2019). A dynamic model of the effects of feedback-seeking behavior and organizational commitment on newcomer turnover. Journal of Management. https://doi.org/10.1177/0149206319850621

Van Solinge, H., \& Henkens, K. (2014). Work-related factors as predictors in the retirement decision-making process of older workers in the Netherlands. Ageing \& Society, 34(9), 1551-1574.

Van Vugt, M., Hogan, R., \& Kaiser, R. B. (2008). Leadership, followership, and evolution: Some lessons from the past. American Psychologist, 63(3), 182-196.

Vlahov, D, Galea, S, Resnick, H, Ahern, J, Boscarino, J., Bucuvalas, M, Gold, J. \& Kilpatrick, D. (2002). Increased use of cigarettes, alcohol, and marijuana among Manhattan, New York, residents after the September 11th terrorist attacks. American Journal of Epidemiology, 155(11), 988-996.

Wanberg, C. R. (2012). The individual experience of unemployment. Annual Review of Psychology, 63, 369-396.

Wanberg, C.R., Ali, A., \& Csillag, B. (2020). The process and experience of looking for a job. Annual Review of Organizational Psychology and Organizational Behavior, 7, 315-337.

Williams, A. L., Parks, A. C., Cormier, G., Stafford, J., \& Whillans, A. (2018). Improving resilience among employees high in depression, anxiety, and workplace distress. International Journal of Research in Management, 9(1-2), 4-22.

Wilmot, M. P., \& Ones, D. S. (2019). A century of research on conscientiousness at work. PNAS Proceedings of the National Academy of Sciences of the United States of America, 116(46), 23004-23010.

Wilmot, M. P., Wanberg, C. R., Kammeyer-Mueller, J. D., \& Ones, D. S. (2019). Extraversion advantages at work: A quantitative review and synthesis of the meta-analytic evidence. Journal of Applied Psychology, 104(12), 1447-1470.

Wisman, J. D. (2013). Wage stagnation, rising inequality and the financial crisis of 2008. Cambridge Journal of Economics, 37(4), 921-945. 